\title{
The moral mechanism of counter accounts: the case of industrial animal production
}

\author{
Eija Vinnarij ${ }^{a,}{ }^{*}$, M atias Laine $^{\mathrm{a}}$ \\ aUniversity of Tampere, Faculty of M anagement, Fl-33014 University of Tampere, Finland. \\ Email: firstname.lastname[at]uta.fi. \\ ${ }^{*}$ Corresponding author: Tel.: +358503187602
}

\section{"Accepted author manuscript" version (postprint)}

\section{Original publication:}

Vinnari, E. \& Laine, M . (2017), The moral mechanism of counter accounts: the case of industrial animal production. Accounting, Organizations and Society, 57, 1-17.

http:// doi.org/10.1016/j.aos.2017.01.002

\section{Acknowledgments:}

This paper has greatly benefited from the comments provided by Katja Aalto, Oana Apostol, Daniel Martinez, Johanna Rämö, Helen Tregidga as well as the two anonymous reviewers. Previous versions of the paper have been presented at the research seminars of Turku School of Economics at the University of Turku and the School of M anagement at the University of Tampere; the 28th International CSEAR Conference on Social and Environmental Accounting Research, St. Andrews, UK (2016); and the Interdisciplinary Perspectives on Accounting Conference, Stockholm, Sweden (2015). The audience comments from those events are also acknowledged with gratitude. 
The moral mechanism of counter accounts: the case of industrial animal production

\begin{abstract}
Counter accounts are hoped to present a counterforce to hegemonic discourses and bring about emancipatory change in societies. While the political potential of counter accounts has, to an extent, been examined in prior accounting literature, there is a need to analyse the associated moral dimension. Our purpose in this paper is to advance theoretical understanding of the transformative potential of counter accounts by examining how they mediate the suffering of oppressed groups and how that mediation could lead to public action. Through a conceptual lens combining media studies and critical discourse analysis, we analyse counter accounts of animal production created by social movement activists in Finland. We find that, in general terms, the transformative potential of counter accounts is associated with their ability to act as a form of moral and political education, by repeatedly suggesting to their audiences how to feel about, and act publicly on, the suffering of an oppressed group. The moral engagement of the counter accounts' audiences takes place through a combination of semiotic cues that simultaneously present the suffering as an objective fact, evoke sympathy towards the oppressed group and present practical options on how to act on the suffering. We also note that counter accounts can give rise to different ethical discourses and practical engagement options depending on the media and semiotic cues employed in their construction. This leaves room for discourses that acknowledge some of the concerns presented in the counter accounts but point towards actions that do not threaten the status quo.
\end{abstract}

Key words: animals; counter accounts; critical discourse analysis; morality; social movements; visual media. 
The moral mechanism of counter accounts: the case of industrial animal production

\section{Introduction}

While humanity is accelerating its collision course with planetary boundaries (Rockström et al., 2009; Steffen et al., 2015), the hegemonic neoliberalist discourse continues to provide a fallacy of corporate benevolence and of the sustainability of the present structural arrangements (Gray, 2010; Tregidga, Milne \& Kearins, 2014). As corporate social and environmental accounts have often been found self-serving and biased (Boiral, 2013; Cho \& Patten, 2007; Spence, 2009; Tregidga, et al., 2014), alternative accounts of organizational and institutional activities have been called for, both to counter hegemonic discourses and to create new ways of seeing, as this is perceived as a potential avenue for bringing about emancipatory change in societies (Gray, Brennan \& Malpas, 2014; Thomson, Russell \& Dey, 2015). A potentially interesting range of such accounts are counter accounts, which can be defined as alternative representations of organizations, industries or governance regimes, produced by civic society groups in order to rectify a state of affairs that is considered harmful or otherwise undesirable (Thomson et al., 2015). This is believed to facilitate steps towards a more socially and environmentally just society (Brown \& Dillard, 2013; Dey, Russell \& Thomson, 2011; Gray, Brennan \& Malpas, 2014) as well as to match corporations' totalizing power with responsibility (Lehman, 1999; Spence, 2009; Gray, 2010).

This study is concerned with counter accounts produced by social movement activists, and the motivation for it can be derived from several perspectives. First, in terms of theoretical motivation, we argue that despite the growing scholarly interest towards counter accounts, there is a lack of theoretical understanding regarding their operational mechanism. In the accounting literature, there has recently been some discussion on the political potential of counter accounts - and counter-hegemonic projects more broadly; in the sense of mobilizing collective action on behalf of those oppressed by hegemonic regimes (e.g. Cooper et al., 2005; Archel, Husillos \& Spence, 2011; Brown \& Dillard, 2013; Tregidga et al., in press). However, to gain a more comprehensive appreciation of the transformative potential of counter accounts we also need to analyse the closely associated moral aspects. This is because a necessary condition for the emergence of political action is the depiction of the oppressed individuals' hardship or suffering in such a way that members of the public come to view the sufferers as a moral cause (Smith, 1759/2010; Boltanski, 1999). Furthermore, different ethical positions result in different views concerning the importance of the suffering, what should be done about it and by whom. Analogously to displays of suffering mediated through television and the internet (Chouliaraki, 2006a, b; 2008; 2013), counter accounts could be envisaged to play an instrumental role in fostering such moral reflexivity. However, as this mechanism has thus far not been investigated in the accounting literature, there is a need for further theoretical elaboration regarding how counter accounts construct a relationship between their audience and the suffering 'other' and thereby stimulate the audience to commit to public action.

Second, the present study is supported by the observation that counter accounts have been the topic of relatively few empirical analyses (Apostol, 2015; Cooper et al., 2005; Gallhofer et al., 2006; Harte \& Owen, 1987; Sikka, 2006; Thomson et al., 2015). Conducted from a variety of perspectives and in different settings, these studies have yielded mixed results regarding the effectiveness of counter accounts. There is thus a further need to investigate how counter accounts could succeed in fulfilling the high hopes set for them in normative and conceptual studies. In particular, scholars have called for more research on how the content, 
form and media of counter accounts relates to their potential to effect social change (Gallhofer, Haslam \& Yonekura, 2015; Tregidga et al., in press), thus providing an empirical motivation for our study.

Third, as a phronetic motivation (Flyvbjerg, 2001), we draw on work highlighting the importance of exploring the connections between accounting and sustainability (Bebbington \& Larrinaga, 2014; Unerman \& Chapman, 2014). It has been argued that despite the burgeoning social and environmental accounting literature, most scholarly work in the field fails to connect to the broader debates on systemic challenges, planetary boundaries and sustainability with a particular investigation of accounting as an emblem of institutionalized calculative practices interacting with those broader processes (Bebbington \& Larrinaga, 2014; Bebbington \& Thomson, 2013; Gray, 2010). Accordingly, our empirical investigation focuses on meat and dairy production, which is an industry benefitting from a taken-for-granted position in societies despite its major direct relevance in the deterioration of the state of the global natural environment (see e.g. Vitousek et al., 1997; Lang, Barling \& Caraher, 2009; Stehfest et al., 2009; M cM ichael, Powles \& Butler, 2007). In keeping with a discursive approach, we maintain here that the way corporations and other social actors depict and represent industrial meat and dairy production (re)constructs not only our understanding of animal production but also human-animal relationships more broadly. Given the significant environmental consequences and, some would argue, ethically untenableı nature of meat and dairy production, we assert that it is of significance which kind of discourses have dominance over the representation of animal farming, since these discourses eventually influence action in societies and are thus real in consequences.

Thus, the purpose of this study is to increase understanding of counter accounts both theoretically and empirically. In particular, we seek to answer the following question: How do counter accounts mediate the suffering of distant others and how, in turn, could that mediation lead to public action? To this end, we analyse empirical data collected in Finland, where animal rights activists have in recent years actively campaigned against the modus operandi of industrial meat and dairy production. A key role in this campaign has been played by videos from pig farms, filmed in secret by activists who have taken advantage of unlocked doors at these low security facilities. The videos, which we conceptualize as multi-modal counter accounts, have been released regularly through dedicated websites since 2007 and to date activists have produced such material from hundreds of farms. In addition to these films, we will also analyse how the counter accounts were featured on television on a prime-time magazine programme, in which clips of the videos were aired to large national audiences.

In exploring these issues, we draw primarily on Chouliaraki's (2006a, b; 2008; 2013) analytics of mediation, which is a phronetically driven, critical discourse analytical approach informed by Boltanski's (1999) sociological work on media, morality and politics. In general terms, we find the analytics of mediation useful for the investigation of counter accounts for at least three purposes. First, it allows us to focus on the relationship between the audiences and 'the other', rather than placing an organization or institution at the centre of the analysis (Brown, Dillard \& Hopper, 2015; Tregidga et al., in press). Second, the framework enables us to shed light on the discursive mechanisms through which counter accounts represent the plight of distant 'others' as a moral cause, constituting the audiences of the accounts as potential activists and presenting them with options for practical engagement. Third, the framework provides analytical tools for investigating written media texts, photos and videos as semiotic rather than linguistic elements ( $ø$ rgensen $\&$ Phillips, 2002), thus facilitating a profound analysis of the visual aspects of counter accounts (Brown, 2010;

1 Drawing on a range of ethical theories, several authors have posited that animal production is also a morally questionable practice (see e.g. Aaltola, 2012; Francione \& Charlton, 2013; Regan, 1984). 
see also M eyer et al., 2013). Especially moving image is becoming an increasingly ubiquitous way of conveying information but has not, to our knowledge, been examined in prior accounting literature. In more particular terms, the analytics of mediation allows us to analyse the social movement activists' counter accounts as multi-modal media texts which, through the use of various semiotic elements, seek to morally engage their spectators and make them committed to act publicly on behalf of the suffering production animals. It also enables us to distinguish between the different meanings that the suffering acquires depending on the medium of dissemination (activist website versus primetime television programme).

Like Tregidga et al. (2014; in press), we believe that in seeking to advance sustainability, scholars should critically engage with and resist hegemonic forms of especially neoliberal discourse (also Gaffikin, 2009). Moreover, we maintain, alongside Gray (2010), Tregidga et al. (2014), and Thomson et al. (2015), that societies need a variety of alternative accounts to counter the self-serving discourse of organizations, industries or governance regimes. Thus, and in seeking to fulfil the moral responsibility of public intellectuals to use our privileged positions to inform and support social progress (Golsorkhi et al., 2009), we will also engage in what Fairclough calls positive critique, involving not only an "analysis of how people seek to remedy or mitigate [social wrongs]", but also "identification of further possibilities for righting or mitigating them" (Fairclough, 2010, p. 7). This implies that in addition to developing further theoretical and empirical knowledge of counter accounts, with this paper we also wish to enhance collective understanding of how such counter accounts could be more effectively used to both resist unsustainable, and subsequently advance more sustainable, organizational and institutional practices.

We believe our research to make two main contributions to prior accounting literature. First, we complement extant knowledge on the transformative potential of counter-hegemonic projects (Cooper et al., 2005; Archel et al., 2011; Brown \& Dillard, 2013; Spence, 2009; Tregidga et al., in press) with an analysis of the thus far neglected moral dimension. In so doing, we also add to the growing empirical literature on the media and methods of counter accounts as an alternative form of conveying information for the purpose of influencing societal decision making (Gray, Malpas and Brennan, 2014; Gallhofer et al., 2015; Thomson et al., 2015). Second, we illustrate the value of Chouliaraki's (2006a, 2008) and Boltanski's (1999) conceptualizations to the study of multi-modal accounts, thus expanding the methodological toolbox of discourse analyses with a rare semiotic framework (Jørgensen \& Phillips, 2002).

The paper proceeds as follows. In the second section, we review prior literature on counter accounts as well as outline the analytical framework of our study. Subsequently, we elaborate on the empirical context of our study and present our methods of data collection and analysis. In the fourth section, we analyse our empirical material through the conceptual lens offered by Chouliaraki's (2006a, 2008, 2013) and Boltanski's (1999) work on media, morality and distant suffering. In the final section, we discuss these findings and present our conclusions.

\section{Literature review}

\subsection{The transformative potential of counter accounts}

The publication of corporate social responsibility reports has become institutionalized as a standard practice in many societies (Bebbington, Unerman \& O'Dwyer, 2014). These voluntary disclosures continue to be hailed as a medium that will help societies tackle social and environmental challenges (see Gray, Adams \& Owen, 2014). It is perceived that as further information about the social and environmental aspects of economic 
activities becomes available, organizational stakeholders and other social agents will take action and thereby the choices made will steer segments of economic activity to new directions.

It seems, however, rather evident that corporate social accounts are not fulfilling the hopes that have at times been placed on them. There is, for instance, a steady cohort of work which argues that such development will remain an aspiration, since corporations and other private organizations engage in social and environmental reporting merely to secure their own private interests (e.g. Aerts \& Cormier, 2009; Boiral, 2013). Looking at the question from a broader perspective, Cho et al. (2015) have argued that such a phenomenon is likely here to stay: the prevailing socio-economic environment sets contradictory institutional pressures on organizations and forces them to engage in organized hypocrisy and to develop organizational façades, thereby limiting the evolvement of sustainability reports into substantive disclosures. Likewise, Gray, Brennan and Malpas (2014) claim that it is somewhat naïve to expect corporate voluntary self-reporting to question the very premises the business world and capitalist market economy is built on (see Spence, 2009).

Furthermore, from a discourse analytical perspective, it can be argued that corporate sustainability practices and the language used therein further reinforce and reconstruct the present structural arrangements and socio-economic order (see Archel et al., 2011; Arnold and Hammond, 1994; also Birkin, Edwards \& Woodward, 2005). Tregidga et al. (2014) for instance argue that through various discursive means, corporations have managed to project an image of themselves as strategically 'good organizations that are not only environmentally responsible and compliant but also leaders in sustainability. Drawing on Laclau and M ouffe's (1985) discussion of discourse theory and the concept of hegemony, Tregidga et al. (2014) argue that corporations have succeeded in constructing an identity as transformed, simultaneously resisting demands of changing business-as-usual and obscuring notions of accountability and transparency (see also Hopwood, 2009; Messner, 2009). The authors identify alternative shadow and silent reports, which have been used to challenge the hegemonic position of the corporate discourse, and call for further critical research on organizational sustainability discourse and its hegemonic forms.

Given the contested role of corporate disclosures, it appears worthwhile to explore more closely the emancipatory potential of other accounts of organizational and institutional activities (Gray, Brennan \& Malpas, 2014; Tregidga et al., 2014). A potentially interesting range of accounts, and the focus of this paper, are the various counter accounts "produced by, or on behalf of, individuals who are beyond, or 'outside', the control of the entity that is the subject of the account" (Thomson et al., 2015, p. 2; see also Dey et al., 2011). Appearing in various forms, counter accounts serve to create alternative representations of particular organizations, practices, or governance regimes by conveying information about their social, economic and environmental impacts. By thus making visible and problematizing something that is considered to have harmful or undesirable consequences, counter accounts ultimately aim to influence societal decision-making and action (Cooper et al., 2005, p. 7; Gallhofer et al., 2015). A more profound exploration of what distinguishes counter accounts from mere 'representations' on the one hand and from more conventional notions of accounting on the other hand is provided in the concluding discussion.

Whether and how the transformative potential of counter accounts could be realized has been subject to both normative and empirical accounting studies. Cooper et al. (2005) for instance report on how they produced an alternative account of student hardship in Scotland with the aim of countering government plans to introduce tuition fees into higher education. Their ultimately successful demand for omitting the fees was framed in Marxist terms as a wider issue of social justice and equality of opportunity in higher 
education, supported by empirical data gathered from a student survey. Reflecting on their experiences, Cooper et al. (2005, p. 973) posit that in order to be successful counter accounts should combine a particular political demand to a theoretically informed understanding of social totality and its contradictions that will enable the activists in question to link their cause to other contemporary social movements' struggles. Likewise, Spence (2009) argues that in order to realize their transformative potential, counter accounts produced by civil society groups would need to expose latent interests and paradoxes in the ways in which society is organized, manifest for instance as social and environmental problems, as well as articulate and disseminate new ideologies and visions around which society could be reorganized.

Further support for counter accounts has been provided in conceptual studies informed by agonistic pluralism (Brown and Dillard, 2013; Brown et al., 2015; Gallhofer et al., 2015; Vinnari \& Dillard, 2016). Taken together, these studies maintain that achieving a large-scale social change towards sustainability requires taking pluralism seriously, in other words fostering polyvocal democratic debate and discussion that provides a fertile breeding ground for new solutions to the perceived problems of the present hegemonic order (Brown \& Dillard, 2013). In this context, counter accounts are perceived as a way of making visible and audible the needs of marginalized constituencies such as animals (Dillard \& Vinnari, 2016), thus enhancing the pluralist quality of the debates. However, as there is still limited knowledge of the various interacting factors potentially affecting the social impact of counter accounts (Gallhofer et al., 2015), there is a need for more research on their role in convincing and enabling individuals to commit to social action (Brown et al., 2015).

A few exceptions notwithstanding (e.g. Harte \& Owen, 1987; Cooper et al., 2005; Sikka, 2006), empirical research focused on exploring the emancipatory potential of counter accounts has only recently picked up and become an increasingly important element of the social accounting literature. One of these more recent studies is Apostol's (2015) case study analysis of how civil society used counter accounts in contesting a major mining project in Romania. Whereas the mining company in its disclosures framed the planned mine as a rather unproblematic project that would bring benefits to the whole society, the counter accounts produced by civil society highlighted social and environmental impacts that were absent or downplayed in the corporate narrative. Apostol (2015) maintains that the counter accounts not only succeeded in problematizing the corporate account, but also revealed the Romanian state's ideological bias towards economic interests instead of social, environmental and cultural aspects. The author concludes that counter accounts have potential to mobilize public action and enable social debate over contested issues, but does not delve deeper into the moral mechanism preceding such mobilization.

Whereas Apostol (2015) draws on discourse analysis to discuss the role of counter accounts in a broad societal setting, Brennan and M erkl-Davies (2014) provide a micro-level account with an in-depth exploration of the communicative interactions between Greenpeace and international sportswear/fashion firms in a conflict over environmental performance. Drawing on stakeholder theory and prior theoretical work on rhetoric and argumentation, Brennan and Merkl-Davies (2014) develop an analytical framework through which they investigate how the parties involved in the conflict used metaphors and other rhetorical means in their press releases in seeking to persuade various audiences to put pressure on the firms. As their result, the authors suggest that the outcomes of such conflict situations depend not only on the attributes of the stakeholders involved and their ability to draw support from other key stakeholders, but also on the rhetorical skills the stakeholders possess. Among other things, they note how Greenpeace used metaphors that resonated with the predominantly Western audiences' values and beliefs, to construe the firms' practices as morally questionable and to underscore the urgency of the situation. Moreover, although Brennan and M erkl-Davies (2014) limit their investigation to written press releases, they highlight that also 
visual rhetoric played an important role in Greenpeace's efforts. The authors go on to note that there is limited research on how stakeholders use images, videos and other non-verbal communication to contest organizational narratives, and hence call for further research that would explore how stakeholders make use of these powerful means of persuasion in their attempts to influence organizational behaviour.

In addition to contesting the activities and plans of individual corporations, civil society groups can use counter accounts in challenging existing and institutionalized governance regimes (Dey et al., 2011). Thomson et al. (2015) have conducted a longitudinal case study to explore how a UK-based anti-tobacco activist organization used counter 2 accounts and other activist practices to confront the tobacco industry and influence tobacco governance in society. M aking use of a dynamic conflict arena framework, Thomson et al. (2015) discuss how the activist organization used various types of counter accounts as the conflict evolved, and how these accounts served in creating a more holistic account of the consequences of tobacco production, consumption and governance. Overall, Thomson and colleagues (2015) argue that such counter accounts can problematize governance practices and contribute to agendas of social and environmental change in societies. However, they also note that the transformational potential of a counter account is contingent upon the characteristics of the conflict arena as well as the tactics and interactions associated with the use of counter accounts. The authors consider further research necessary for, inter alia, exploring the appropriateness of the counter accounts' content, the media and methods used in the counter account, and the nature of the oppressed groups on behalf of whom the account is prepared.

Taken together, this emerging body of prescriptive and descriptive work has enhanced our understanding of both the expectations and the practices related to counter accounts. It is evident that counter accounts can be used in a variety of settings, and that different forms and media of counter accounting may be drawn upon in seeking to engender social change. Moreover, as a whole the empirical work has also provided support to the argument of Dey et al. (2011) that counter accounts can make thinkable and governable such issues that are regarded as unthinkable or ungovernable by those in power in a particular setting. Yet, as the work reviewed above has largely focused on the political potential of counter accounts, there is a need for further scrutiny of the mechanism involved in constituting audiences as both moral and political actors. This involves replacing the predominantly corporation-centric view of extant studies with a focus on the relationship between the audiences and those suffering under present structural arrangements.

In this paper, we investigate how social movement activists used counter accounts in an attempt to create a moral relationship between the audience and the suffering 'others', and thereby sought to create change in the hegemonic discourses and taken for granted institutional structures delineating how the keeping, production and consumption of farm animals is framed within society. Our investigation of these issues is informed by the analytical framework elaborated in the next section.

\subsection{Morality and the mediation of distant suffering}

Our analysis draws from work on distant suffering as developed by Boltanski (1999) and considerably expanded by Chouliaraki $(2006 a, 2008,2013)$ into a critical discourse analytical approach, the analytics of mediation. Both Boltanski and Chouliaraki are concerned with the ethical disposition of Western publics towards the misfortune of distant 'others', be these victims of a natural disaster, disease or warfare. At the core of Boltanski's (1999) sociologically oriented work are three paradigmatic 'topics' of publicly staging

2 Thomson et al. (2015) employ the term 'external accounts', which we have replaced with counter accounts to maintain consistency of expression throughout this paper. 
suffering - pamphleteering, philanthropy and sublimation; each of which is associated with a specific moral value and emotional register.

Chouliaraki in turn is interested in the role of multi-modal media, such as television and the Internet, as a form of moral education that can awaken Western spectators' sense of responsibility towards suffering individuals in faraway locations. She has developed the analytics of mediation (Chouliaraki, 2006a et seq) for the purpose of critically studying the semiotic mechanisms by which multi-modal media construct a moral relationship between the spectator and the distant 'other', suggesting ways in which the spectator should feel and act on the other's suffering. Boltanski's (1999) three topics form one part of this analytical grid.

In their analyses of moral values and morally acceptable behaviour in the context of distant suffering Boltanski (1999) and Chouliaraki (2006a et seq) draw on the strand of philosophical thought known as virtue ethics3, which places emphasis on virtues, or the moral character of an actor (Annas, 2006). Both authors appropriate certain ideas from Adam Smith's virtue ethical presentation, the theory of moral sentiments (Smith, 1759/2010). In this presentation, Smith focuses on describing - as opposed to prescribing, how public values emerge and are subsequently applied when making moral judgments. As an Enlightenment philosopher, Smith awards a prominent role to sympathy and imagination as the founding elements of morality4. He maintains that human beings have a natural capacity for 'fellow-feeling' towards a suffering individual, deriving from our ability to imagine how we would feel in a similar situation (Smith, 1759/2010, Part I, Chapter 1, p. 5). Likewise, sympathy forms the basis for our evaluation of other individuals' actions towards the sufferer. If we sympathize with the sufferer's gratitude towards a benefactor or her resentment towards a persecutor, we consider the associated actions to be respectively morally justified or unjustified (ibid.). Smith also introduces the idea of the internal spectator, referring to an individual's ability to see herself in the eyes of others and judge her own actions based on that introspection. Boltanski (1999) applies these ideas to media representations of distant suffering, arguing that such representations usually take the form of one of three discursive 'topics', each of which makes a distinct moral proposal to the spectators depending on the actors shown in the vicinity of the sufferers. The three topics, which are embedded in Chouliaraki's (2006a et seq) analytical grid, will be elaborated further below.

Chouliaraki's (2006a et seq) work is also driven by Aristotle's virtue of phronesis (prudence), which entails studying social life from the perspective of what is 'good or bad for man'. However, her take on virtue ethics is distinct in the sense that she combines the phronetic perspective with a poststructuralist (Foucauldian) interest in the power effects of discursive formations (Chouliaraki, 2013, p. 205). Such a combination, she argues, enables the examination of the conditions under which a specific practice may turn out to be 'good or bad' for a certain group of individuals at a certain point in time (on similarities between phronesis and poststructuralist inquiry, see Flyvbjerg, 2001, pp. 110-128). The epistemological implication of this position is that Chouliaraki rejects 'grand theories' of ethical inquiry that she sees as being based on either a foundationalist view of universal moral principles, or a relativist epistemology of purely particular,

\footnotetext{
3 The other two major strands of ethics are consequentialism and deontology. Consequentialism holds that the morality of an act should be judged based on the consequences of that act or of something associated with that act (Sinnott-Armstrong, 2015). A well-known consequentialist theory is utilitarianism, according to which the morally right action is the action that produces the most good (see e.g. Bentham, 1789/1961; Mill, 1861/1998). Deontological theories in contrast emphasize moral duties and rules, judging the morality of choices by criteria that are different from the states of affairs following from those choices (Brink, 2006).

4 The idea of the emotive body, rather than reason, as the basis of moral consideration was discussed already by de M ontaigne in his essay "Of Cruelty" dating from 1480, but became more pronounced only later in the works of Enlightenment philosophers (see e.g. Aaltola, 2012).
} 
ungeneralizable ethical values. In line with Aristotle's interest in particular events as manifestations of public values, she considers mediated displays of suffering to shape, and be shaped by, the public values that prevail in a given socio-historical context (Chouliaraki, 2008, p. 7).

Following Foucault (1981, p. 82), Chouliaraki (2006a, b; 2008) employs the term 'analytics' as distinct from a 'theory' of mediation to designate her framew ork for examining how media discourse displays the misfortune of distant 'others' and in so doing performs, albeit does not determine, the spectators' identities. She believes that by exposing audiences to suffering and presenting them with a spectrum of options on how to relate to and act on it, contemporary media can nourish their imaginations and thus act as a significant form of moral and political education (Chouliaraki, 2008, p. 838; see also Smith, 1759/2010, Part V, Chapter 1). In particular, she views the mediation of suffering as a public-political process that has the potential to constitute a spectator as not only a moral actor, who feels compelled to act based on empathetic identification with the sufferer, but also as a political actor, "someone capable of seeing him/herself thinking with and acting in a collective 'we' of other actors for a common cause" (Chouliaraki, 2008, p. 198). However, she gives equal consideration to the possibility that mediation can also fail to cultivate a sense of solidarity towards distant others by encouraging 'us' spectators to exclude the suffering 'them' from our sphere of moral and political consideration. A key question in this respect is how do media texts represent the suffering; is it articulated in such a way that the spectator becomes emotionally engaged in the sufferer's cause and feels a moral responsibility to act upon it, or is it articulated in a way that does not appeal to her ethical sensibilities, and therefore as something she need not care about? In order to answer this question, the analytics of mediation examines media texts along two main dimensions, multi-modality and multi-functionality. The study of multimodality focuses on technical, visual and verbal means of representation that construe the on-screen suffering as the spectators' immediate reality and establish (or not) an emotional connection between the audiences and the sufferers. The investigation of multi-functionality complements this analysis by focusing on how the representation of space, time and moral agency results in the articulation of certain public values and proposals for the audiences' practical engagement with the sufferers. In the following we will elaborate on both dimensions, highlighting those aspects that are most relevant for the present investigation. A compilation of Chouliaraki's (2006a) framework with indicative analytical questions is presented in Appendix I.

Multi-modality

In critical discourse analysis (CDA), multi-modality is a term used to characterize texts that comprise elements from a variety of semiotic systems such as language; moving or still image; and sound ( ørgensen \& Phillips, 2002). The study of multi-modality therefore involves the analysis of not only the verbal but also the visual and aural aspects of a text. Similar to other variants of CDA, and post-structuralist inquiry in general, the analytics of mediation does not view meaning as a fixed property of signs but as a contingent and relatively unstable feature. More precisely, the meaning that emerges from a particular event of suffering is considered to vary according to the medium that is used to relay the event (Chouliaraki, 2006a, p. 159). For instance, a predominantly visual representation of suffering vests the latter with a stronger sense of urgency than if it were represented only through the medium of spoken or written language (Chouliaraki, 2008, p. 76).

The analysis of multi-modality entails paying attention to three aspects that provide a media text with a distinct sense of authenticity and emotional appeal: mode of presentation; visual and verbal aspects; and aesthetic quality (Chouliaraki, 2006a, p. 160). The mode of presentation refers to choices regarding the locations from which an event is recounted (in studio and/or on-site) and the media used to tell it. These 
choices give rise to a particular form of narrative realism, which may be perceptual, categorical or ideological. Perceptual realism relies on the power of visual perception, that is, people believing that what they see with their own eyes is real. Categorical realism is evoked by appealing to audiences' emotional sensibilities as opposed to tangible facts, while ideological realism is brought about by appealing to spectators' moral sensibilities, in other words her beliefs regarding how the world should be.

In addition to mode of presentation, the type of realism produced by a multi-modal text is also dependent on its visual and verbal elements. The visual mode is particularly significant, as an impression of the authenticity of an event requires a visual testimony, which simultaneously places a moral burden on the audience as witnesses (Chouliaraki, 2006a, p. 161). Here, the analytics of mediation pays attention to the type of visual material employed, such as graphic, photographic or video. In the case of video image, aspects analysed include (Chouliaraki, 2006a, p. 162) the point of view of filming, camera angle, how actors are framed, and what kind of movement takes place in the image. The verbal elements in turn can either accompany or expand on the visuals in descriptive, normative or dramatizing tones. The linguistic elements organize and categorize people, spaces and times with the help of three complementary narrative functions: 'descriptions', 'narrations proper' and 'expositions'. The function of description makes the strongest claim to objectivity by telling what we see in the visual elements of the media text. Narration in turn relays events as in a piece of fiction having a chronological plot and applying literary conventions such as those related to opening and closure. Finally, in exposition an ethical statement related to the depiction of suffering is integrated in the narrative, telling the spectator how she should relate to it in moral terms.

Aesthetic quality makes up the third aspect of multi-modality, summarizing the overall effect produced by the mode of presentation and the visual-verbal elements in terms of Boltanski's (1999) three topics for the public staging of suffering: pamphleteering, philanthropy and sublimation. Each topic is associated with the symbolic figures of persecutors or benefactors, whose presence or absence further suggests to the spectators how they should feel about the suffering. The topic of pamphleteering depicts the suffering individuals together with their persecutors, for instance child prostitutes with their pimps, evoking the audiences' anger and indignation towards the latter. The topic of philanthropy invokes the spectators' tender-heartedness and gratitude towards the benefactors helping the sufferers, by showing for example how NGO workers provide on-site disaster relief to earthquake victims. Finally, the topic of sublimation, which features neither persecutors nor benefactors, distances the spectator from the actuality of the event and invites her to contemplate the suffering in a detached manner.

We will now turn to the second dimension of Chouliaraki's (2006a) analytics of mediation, multi-functionality, which delves deeper into the content of the public values articulated by mediated events of suffering as well the ways of taking action that are offered to a spectator who has become emotionally engaged to the sufferer(s). The aspects analysed in this context include spacetimes and agency.

\section{Multi-functionality}

The fundamental assumption underlying multi-functionality is that both verbal and visual semiotic modes create meanings that fulfil more than one social function at once, specifically the need to name and represent the world as well as the need to interact with other individuals (Chouliaraki, 2008, p. 84). The study of multifunctionality takes place through critical discourse analysis (CDA), which sees the verbal and visual choices of mediation as indicative of the power of media to represent individuals as 'us' and 'them' and to propose a certain disposition that the spectator should take towards the suffering 'other'. When analysing the power of media to classify individuals, CDA is employed to examine how a scene of suffering is constructed within a 
specific spacetime that expresses the moral distance of the sufferer from the audience as well as the urgency of the action. Suffering can be represented either in a categorical fashion as taking place in a particular place in the present, the past or the future, or in a more ambivalent fashion involving one or more spacetimes. According to Chouliaraki (2006b, p. 88) spatio-temporally complex representations of suffering possess the maximum moral appeal and potential for engagement because they lessen the 'othering' of the sufferer by highlighting multiple realities relevant to the suffering as well as by expanding our horizon to comprise its historical context.

When analysing the power of media to suggest a particular orientation towards the 'other', CDA is applied to investigate the agency of both the sufferer and those present in the same scene with her. The ways in which forms of agency are represented in the media text has the effect of positioning certain sufferers as being similar to us, and therefore deserving of our sympathy-driven efforts, and others as those who are unlike us and not equally worthy of our pity. A key aspect in this respect is humanization, "a process of identity construction that endows the sufferer with the power to say or do something about her condition, even if this power is simply the power to evoke and receive the beneficiary action of others" (Chouliaraki, 2006a, p. 170). The semiotic choices affecting this process relate to whether or not the sufferer is given a voice and interiority and whether or not she is depicted as communicating with others on the site or with the spectator.

When applied to the context of animal rights activism, the term 'human' and its derivatives are problematic as they suggest that such caring and empathy are to be reserved exclusively to members of our own species. To avoid such connotations, in our application of the analytics of mediation we will replace 'humanization' with the more species-neutral term kindredization. Although it may sound somewhat awkward at first, we argue that in addition to avoiding the trap of anthropomorphism the term has the benefit of designating a key feature in human-animal relations: the acknowledgement of being related through common ancestors.

The dimensions of spacetime and agency are key in fostering audiences' moral imagination, that is, their ability to both recognize "the irreducibly distinct quality of the other" and to develop "an empathetic sense of the other" as a similar, sovereign individual (Chouliaraki \& Orgad, 2011, p. 343). In an ideal case, such moral education through mediated representations of otherness would eventually lead to the emergence of a cosmopolis: "a space wherein we can imagine ourselves caring for others not because they are reflections of ourselves but precisely because they are different from us" (ibid., p. 344) 5.

Another important aspect in analysing agency in mediated events of suffering relates, again with reference to Boltanski's (1999) three topics, to the dynamics between the sufferer and a persecutor or benefactor. Through these symbolic figures, the three topics articulate different values and present the spectators with options on how to act on the suffering. Pamphleteering appeals to the spectators' sense of justice and solidarity and contains the possibility of constituting them as moral actors who decide to correct the injustice inflicted by the evildoers by participating in public life. Such public action can take the form of simply relating to others what one has seen, participating in street demonstrations, or volunteering in a non-governmental organization (ibid., p. 188-190). Yet, as pamphleteering operates through the logic of complicity whereby the audiences themselves are pinpointed as being partially to blame for the suffering, it may also lead to compassion fatigue and apathy (Chouliaraki, 2010, p. 111). Philanthropy, which articulates the values of

\footnotetext{
5 Although the notion of cosmopolis may seem contradictory to the idea of humanization/kindredization, we understand these phenomena as consecutive phases in the moral development of humankind. Ideally, after we have first acknowledged that the 'other' is in a fundamental sense very similar to us, we can learn to care for them without looking for apparent similarities.
} 
compassion and care, suggests to the spectators that instead of a personal commitment the morally acceptable action is to support the beneficiaries operating on the site of suffering by donating money. However, by prioritizing the need to alleviate the suffering immediately, appeals to audiences' tenderheartedness gloss over fundamental structural injustice (Chouliaraki, 2010, p. 114; see also Arendt, 1973). Finally, sublimation is the most ambivalent of the three topics in terms of inducing ethical and practical action. Lacking the impetus of grand emotions, sublimation may involve a 'radical rejection of pity' (Boltanski, 1999, p. 132); yet by allowing the spectators to focus on the suffering instead of their own feelings, sublimation enables thoughtful reflection of the circumstances that have led to the suffering (Chouliaraki, 2008, p. 92). This ambivalence highlights a perennial tension in the mediation of distant suffering between emotional appeal and objective reflection, between emotional identification and reflexive judgement (Chouliaraki, 2008, p. 216).

While both Boltanski (1999) and Chouliaraki (2006a, 2008) admit that in practice these three analytically distinct topics often appear in combination in a singular mediated display of suffering, they differ in their views regarding the effectiveness of the dominating topic. Boltanski (1999) refrains from explicitly ranking the topics in order of moral or political effectiveness, whereas Chouliaraki $(2008$, p. 193) suggests that it is the ideological realism embedded in pamphleteering that renders the topic most successful in articulating suffering as a cause for practical action by associating reality with questions of justice.

Having thus outlined our analytical framework, we will next provide a concise description of the data and setting of our study.

\section{Data and setting}

\subsection{Animal rights activism in Finland}

The social movement that we examine in this paper is animal rights activism, which can be perceived as the radical offspring of the more traditional movement that focuses on animal welfare. A fundamental moral philosophical difference between the two groups is that the welfarists approve of the keeping of animals for various human purposes and only try to alleviate unnecessary suffering, while animal rights activists seek justice for all forms of life by trying to completely abolish the use of animals for food, clothing, medical research and entertainment (Francione, 1996). In Finland, this difference is reflected in the aims of the three major animal issue organizations: The Finnish Society for the Protection of Animals (SEY), Animalia, and Oikeutta Eläimille (OE). When positioned on a continuum, SEY is closest to the pole of traditional welfarism and $\mathrm{OE}$ to that of radical abolitionism, while Animalia occupies the middle ground, campaigning simultaneously for welfare improvements and the realization of animal rights (Vinnari \& Vinnari, 2005). OE, which is the focal movement of this paper, was established in 1995 by activists disappointed with the ideology of SEY and Animalia6 and at least partially inspired by the US-based organization PETA, or People for the Ethical Treatment of Animals (Konttinen \& Peltokoski, 2004). During the same year, Finnish animal rights activism surfaced into public consciousness when two individual activists invaded a fur farm and released hundreds of animals from their cages into the surrounding environment. This act was the first of its kind in Finland and raised considerable discussion, with the majority of the population denouncing the use of such unlawful means. Even though the public outrage eventually subsided, animal rights activists operated more

6 OE has no official name in English, translating loosely into "justice for animals". According to an OE representative (personal communication), at the time of writing in November 2015 the organization had some 200 active members and an additional 1,000 individual sponsors who provided regular monthly donations. 
conventionally for several years, campaigning against animal production mainly through the dissemination of leaflets as well as information events and peaceful demonstrations held to oppose in vivo animal experiments or fur sales. During these campaigns, OE occasionally joined forces with SEY and Animalia, the latest example being a nationwide (ultimately unsuccessful) initiative in 2012-2013 to abolish fur farming in Finland.

In recent years animal rights activists' campaigning has again assumed a more radical and politically visible form: taking advantage of non-existent security measures at Finnish animal farms, activists have produced videotaped material from within the doors of almost two hundred piggeries, henneries, broiler houses and cattle farms. The videos have been released in batches in 2007, 2009 and 2011, and incrementally from 2013 onwards, often to be shown first on national television and then as downloadable clips on the websites7 hosted by OE. Officially, the websites are the only connection between the activists and $\mathrm{OE}$ as the organization has not taken credit for the filmings and neither have the activists referred to themselves as its representatives.

\subsection{Empirical material and analysis}

Our study and the interpretation presented in this paper are based on contrasting two datasets. First, our data includes the piggery videos the animal rights activists have filmed and set to be freely downloadable on specific websites. Of all the activists' campaign material, our analysis focuses on these videos and the associated website texts and functionalities since they represent a promising new form of counter accounting (Gallhofer et al., 2006) with which the activists hope to further their cause. We narrowed the scope of the empirical material to the piggeries as these facilities have been subject to activist filming most often and in total constitute roughly a half of the activists' video material. As the overall volume of these visual counter accounts is vast, with material acquired from over a hundred pig farms, and as the videos resemble each other in terms of their fundamental idea, setting and presentation, we have not considered it necessary to analyse all of them but have gone through a random selection of twenty videos to get a sense of their common features.

Second, our empirical material includes two editions of A-Studio, a leading prime time news magazine that has run on national television already for several decades. The programme focuses on current social, political and economic topics, and seeks to provide both carefully contextualized analysis and a forum for discussion. A-Studio reaches a wide audience as each episode of the programme attracts approximately 0.6 million spectators8, in other words about 12 per cent of population aged 15 or older. In this paper we provide an indepth analysis of two episodes (from a total of four) in which the activist videos were discussed and/or shown. Both episodes are 45 minutes long, aired respectively on 28.11.2007 and on 28.10.2015. We selected particularly these episodes since the 2007 episode coincided with the release of the activists' first set of video clips, while the 2015 episode is the most recent one.

In terms of analytical method, we will as discussed above draw on Chouliaraki's (2006a et seq), and to some extent Boltanski's (1999), work on the mediation of distant suffering. A more detailed discussion of our method is thus presented in section 2.2 (see also Appendix 1). On a more general level, and as has been alluded to above, the work at hand draws on CDA. Belonging to the rather broad family of discursive approaches (see Alvesson and Kärreman, 2011, and the subsequent discussion), CDA can be characterized as

7 www.tehotuotanto.net; $\underline{w w w . s i k a t e h t a a t . f i} ; \underline{w w w . e l a i n t e h t a a t . f i}$

8 According to TV audience measurement service Finnpanel (http://www.finnpanel.fi/en/) 
being interested in "how the process of social construction leads to a social reality that is taken for granted and that advantages some participants at the expense of others" (Phillips and Hardy, 2002, p. 15). In general, we perceive that the way both text - including concepts, expressions and metaphors; and visual imagery (Hardy and Phillips, 1999) are used in society has a role in the construction of social reality, subsequently affecting action (see Dryzek, 1997). By intertwining with social practices in various social contexts the language and the visual create discourses, which affect our understanding of reality and have effects on our actions in societies. Further, CDA posits a dialectical relationship between discourses and other elements of the social whereby discourses are seen as both constitutive of, and constituted by, the social world and its practices9 (Jørgensen \& Phillips, 2002, p. 19). Typical for CDA is the way it "foregrounds the interrogation of the hegemonic and contested nature of discourse(s) with respect to privileged and marginalized accounts and perspectives", giving it popularity among scholars interested in studying power and associated relations (Phillips \& Oswick, 2012, p. 457).

In practical terms, the analysis of the empirical material was conducted as follows. First, both authors individually watched twenty randomly selected video clips filmed by the activists as well as the two episodes of A-Studio. We then discussed these materials and our interpretations of them in the light of the analytics of mediation to arrive at a joint interpretation. The scope of the investigation is limited to our own consumption of the media texts, that is, we have not tried to establish how the meat industry or other societal actors have interpreted these films. This approach is in line with the empirical works of Chouliaraki (e.g. 2004, 2006c, 2008, 2010), in which she analyses media representations of suffering from her own perspective only. Furthermore, we are not trying to establish whether the videos and the television programme present a true and fair view of animal production in Finland. In this sense, the analytics of mediation is a useful framework as it does not attempt to judge whether a media text is objective or not but "tactically sidelines such questions in order to analyse how norms of right and wrong are produced in the course of the footage itself and how such norms construe a certain version of the [events shown]" (Chouliaraki, 2006b, p. 263). Finally, although our analytical emphasis was on the discursive and semiotic aspects of these counter accounts, we also paid attention to their positioning as part of a broader repertoire of activist strategies. This enables us to establish linkages between our findings concerning the moral dimension of counter accounts and the prior accounting literature examining their emancipatory potential.

We will now turn to our empirical material in order to analyse how the counter accounts produced by the animal rights activists represented the suffering of the production animals, constructing ethical discourses and proposing practical possibilities for the audience to act on behalf of those suffering.

\section{Counter accounts and the cultivation of moral reflexivity}

\subsection{Counter accounts on activist website: seeking justice through the logic of complicity}

\section{Multi-modality}

The mode of presentation of the animal activists' counter accounts is moving image (videos from inside the production halls; no voiceover) accompanied by brief written texts. As concerns the visual plane, the films have been shot in dark production halls illuminated only by the activists' flashlight. The camera's point of view is involved, being as close to the animals as possible without stepping into the pens. The angle of filming is mainly oblique, showing the animals slightly from above, but there are also occasional direct shots taken

9 By distinguishing between discursive and non-discursive aspects of the social CDA differs from the post-structuralist discourse theory of Laclau \& M ouffe (1985), which holds that the social is entirely discursively constituted. 
from the level of the animals' gaze. M ovement is visualized in two main ways, through the camera zooms and the animals' activities. The camera occasionally zooms in on an individual pig to provide 'raw' images of prominent wounds and abscesses. It also moves along the piggery structures to depict thick layers of dirt and dust on the floors and walls. The pigs' activity in turn is seemingly random movement in various directions in and out of the camera frame, gnawing at the metal bars, chasing and biting each other or poking at a carcass. These often frantic movements are contrasted with the immobility of injured animals lying on the floor. The aural backdrop to this visual composition is the constant humming of the ventilation equipment and the pigs' grunting and squealing. Taken together, these audio-visual elements vest the counter accounts with the quality of a first-hand testimony that already places the spectator in the moral role of a witness (Chouliaraki, 2006a, p. 161).

On the verbal plane, the onscreen events are framed by what we here conceptualize as a 'layered' narrative, which varies according to the physical distance between the verbal and visual elements. The first layer consists of concise written texts situated in the immediate vicinity of each video, so that they are visible to the spectator even as she is watching the videos. The following is an illustrative example of a first-layer text:

"This large pig farm looked really bad. It was very dirty. Many animals had hernias. One pig was rotting in the pen, and another one was stuck between pens and was thrashing there without getting loose. Some of the pigs were biting each other's ears into shreds."

In terms of narrative type (Chouliaraki, 2006a), these texts can mainly be characterized as descriptions that use language to establish a relationship of factual correspondence where the linguistic elements refer to a pre-existing external reality, that is, the moving image. The texts also guide the spectator in advance, telling her what she should be looking for in the image (see Davison, 2010). The dominant descriptive narrative is supplemented by occasional elements of exposition that can be taken to appeal to the spectators' moral sensibilities, such as the above evaluation of the farm in question looking "really bad". Interestingly, the amount of exposition increases as we move further away from the videos to look at other sections of the website that can be accessed through the menu at the top of the page. These sections contain 'second-layer' written texts that not only refer to the visual elements but also expand on them by connecting the animals' conditions to the institutionalized practice of animal production:

"These videos show that animal suffering is an inextricable part of animal production where animals are seen as products and commodities."

Some of the second-layer texts are purely expository as they contain normative proposals and moral judgements that explicitly articulate the value of justice:

"The greatest injustice in animal production is that there is no justification for the use of animals."

Taken together, the visual and first-layer verbal elements described above are indicative of a strong reliance on the power of the image, evoking the 'this-is-it' type of perceptive realism (Chouliaraki, 2006a) whereby the spectator is invited to consider what she sees with her own eyes to be true and to draw her own conclusions. The core elements of the counter accounts thus make a claim to facticity, to providing a 'true and fair' view of animal production in Finland. With reference to Boltanski's (1999) topics for the public staging of suffering, the emphasis on accuracy and facticity refers to the topic of sublimation whereby the audiences are invited to rationally contemplate the suffering without indulging in grand emotions. Although sublimation as a communication strategy may appeal to those who abhor sentimentality towards animals, it 
runs the risk that, due to want of emotional arousal, the audiences do not come to view the animals as a moral cause. This is especially so as in the absence of an organizing verbal voiceover the spectator can only see the pigs' physical condition, while their mental state remains largely unknown to her. The suffering she sees thereby acquires a predominantly bodily meaning. On the other hand, the graphic images and the expository elements of especially the second-layer texts give rise to ideological realism (Chouliaraki, 2006a), which attempts to appeal to the spectator's sense of sympathy and subsequently morality by proposing that the pigs' suffering is not only an objective reality but also an unjustified state of affairs. This is representative of pamphleteering (Boltanski, 1999), a topic meant to evoke the spectator's private emotion of anger.

Overall, the extent to which the activists' online counter accounts can be considered to represent the suffering animals as a morally worthy cause depends on which parts of the media texts are examined. In addition, whether a morally indignant spectator's private feelings of guilt and anger lead to a rejection of the moral plea or are channeled into public action depends on how the counter accounts depict spacetimes and agency, elements that we will examine next.

Multi-functionality

As concerns space, the presence of the activists' camera within the production halls, its involved point of view and the intense visualization of the pigs' diverse injuries serve to reduce the physical distance between the audiences and the animals. On the other hand, at the same time the technology of mediation makes itself evident as the clips consist of several shorter shots taken from various locations within the production halls, so the spectator ultimately remains at a certain safe distance from the events taking place. From the perspective of time, the visual and verbal elements provide a different sense of when the suffering has taken place. The sense of temporal proximity conveyed by the involved camera is undermined by the past tense of the first-layer texts ("this large piggery was dirty"). Yet, the second-layer texts in other sections of the website are predominantly in the present tense:

"In harsh conditions these intelligent animals become quickly frustrated and start to take it out on their fellow creatures. Lying on hard concrete floors causes for instance hoof injuries and arthritis."

Thus, the counter accounts mainly represent the suffering in a categorical fashion (Chouliaraki, 2008), as taking place in fairly uniform and replaceable spaces in the present. This results in a spatio-temporally simple representation that underlines the urgency of alleviating the suffering that is taking place right now. Such simplicity does little to mitigate the moral distance between the pigs who suffer and the human beings who watch as the latter are not invited to contemplate on the historical or structural context of the situation. This re-enactment maintains the animals in the category of 'others', an effect reinforced by the representation of their moral agency.

Concerning the agency of the sufferer, in the absence of an organizing voiceover, it is mainly the moving image that could create a moral relationship between the spectator and the sufferer by representing the latter as a member of a kindred species. The videos literally give a face and voice to the animals but mainly as a grunting, squealing mass. As the spectator cannot tell the difference between individual pigs, understand their communication, or get a sense of the depth of their consciousness, the gap between 'us' and 'the other' remains largely unbridged. The pigs' identity does not emerge from the videos as that of sovereign individuals constrained by unjust social structures (Chouliaraki, 2010), but as a faceless mass physically suffering because of their immediate surroundings. The collective terms used in the first-layer narrative ("pigs", "the animals") do little to fade this impression. 
However, yet again the second-layer verbal texts elsewhere on the website are more explicit and morally loaded, making an attempt at kindredization by pointing towards a fundamental similarity between human beings and animals:

"It is true that animals cannot speak, write or demand respect for themselves, but neither are all human beings capable of doing those things. The only meaningful thing from the perspective of animal use is sentience (...) We do not have the right to eat other sentient beings, be they chicken, pigs, dogs or people."

In regards to other forms of agency present on the scene of the suffering, the previously identified topics of sublimation and pamphleteering suggest that other agents are either completely absent from the scene or embodied in the symbolic figure of the persecutor. Indeed, no other agents, concrete or abstract, can be identified on the visual plane or from the first-layer texts. In the second-layer texts, references to persecutors are somewhat more ubiquitous but point towards different entities at various levels of abstraction, as illustrated by the following three examples:

"The producers' rhetoric reduces animals to production units."

"Pigs butchered for the Christmas table live a stressful life imbued with suffering, locked away in cramped pens with no stimuli."

"Respect the value of animals and become a vegan already today."

In the above expressions, the persecutors identified include, respectively, those involved in the meat production supply chain ("producers"); national culture and customs that maintain the institution of meat consumption (serving ham at Christmas dinner); and the consumers themselves (indicated by the imperative clause directed at the reader). Since institutions are abstract and introspection of one's own dietary habits could lead to personal discomfort, it is likely that "producers" will be identified as the culprit and the target of an indignant spectator's anger.

In terms of how to act on the suffering, the images and the first-layer texts of the activist website remain faithful to the topic of sublimation, trusting the spectators to draw their own conclusions and decide on the most appropriate course of action. Similarly true to the topic of pamphleteering, the second-layer texts offer three concrete options for correcting the perceived injustice: trying vegetarianism (with hyperlinks to vegetarian recipes and the Vegan Society's website); acting on behalf of animals by speaking to friends, writing op-eds, or joining the animal rights movement (with a hyperlink to a list of the movement's local chapters); and supporting animal rights work (with a hyperlink labelled "Click here to make a donation"). While the options of speaking and donating correspond directly to the forms of public action discussed by Boltanski (1999) and Chouliaraki $(2006 a, 2008)$ in the humanitarian aid context, becoming a vegetarian is unique to the animal rights setting in that it makes explicit the spectator's complicity in the animals' suffering and asks her, before anything else, to drastically change her consumption habits. Analogous appeals for personal change can be perceived for instance in the human rights or labour rights setting, where individuals are asked to change their consumption habits by boycotting products that involve child labour.

To summarize, our application of the analytics of mediation to the animal activists' online counter accounts suggests a very strong reliance on the power of the moving image to create a moral relationship between the spectator and the sufferers and to suggest that the spectator should somehow act on the suffering. The dominant topic of the counter accounts is sublimation, which, due to the lack of verbal voiceover, spatiotemporal simplicity and the problems of kindredization, vests the suffering with an ambiguous, largely 
physical meaning and may fail to morally engage the spectators. The secondary topic of the counter accounts is pamphleteering, which portrays animal production as an injustice caused by several different culprits, including the spectator, and suggests that the morally most correct option is personal change, followed by public action and philanthropy. Operating through the logic of complicity, such moral appeals may result in compassion fatigue and the rejection of the activists' moral plea.

\subsection{Counter accounts reproduced in television: seeking justice within the status quo}

Multi-modality

Compared to the rather simple verbal, visual and technical means with which animal suffering is presented on the activists' online counter accounts, the corresponding elements of the A-Studio episodes can be characterized as being substantially more complex and diverse. The visual frame of the programmes is the studio interior, which is interrupted to move to an edited insert that contains excerptsfrom the activist videos with added voiceover. The dominant types of narrative realism evoked by the programme episodes are perceptive realism and ideological realism, with occasional instances of categorical realism. The three types are sometimes intertwined, as illustrated for instance by the studio host's framing of the insert:

"Before we roll the tape, I just want to say one more thing. Our aim is not to claim that this would be the typical picture of Finnish agriculture. Instead we want to ask why such things take place also in Finland. The insert contains a lot of shocking footage." (A-Studio 2007)

This statement simultaneously convinces the spectator that what she is about to see is the truth (perceptive realism), suggests that this truth violates commonly held certainties about what Finnish animal production looks like (ideological realism), and grants legitimacy to strong emotional reactions provoked by the exceptional nature of the visual material (categorical realism). The statement already equips the spectator with a certain disposition - that the events to be shown are at the same time authentic, morally questionable, and emotionally disturbing.

Ideological realism is most apparently evoked in the prelude to the first episode's insert. When it begins, on the visual plane we see moving image of cows grazing serenely on a lush green meadow. On the aural plane, we hear a popular tune from the 1960s, referring to the bliss of living in the countryside. On the verbal plane, the host's voice begins by saying: "This is what it should be like. And this is how many people think it is: In Finland, also production animals lead a happy life". Then the camera cuts into a view of a country road and as the screen begins to turn darker the same voice continues: "But tonight we drive into the darkness to see what else, besides idyll, can be found on Finnish farms." Together, the visual and verbal elements of this sequence present the spectator with a clear normative proposal: that animal production as such is morally acceptable as long as the animals are "happy" and that this is, in fact, the norm on Finnish farms. The sinister events that are about to be shown represent violations of that norm, and must be further investigated by the journalist.

Perceptive realism is evoked especially in the verbal expert commentaries that accompany compilations of the activist videos:

"What you can see here is tail-biting. It results from exposure to a variety of environmental stress factors, such as lack of stimuli and low levels of hygiene." (Animal welfare professor, A-Studio 2007) 
Through this and similar statements, the on-screen suffering acquires an extra-pictorial meaning as the interpreting voiceover not only describes what can be seen, that is the pigs' physical state, but also expands on it by linking the physical wounds to the non-visible mental problems behind them. When such factual descriptions blend into normative proposals in the expert commentaries, it is very often with reference to legislation in force:

"The Animal Protection Act says that the facilities must be kept clean and hygienic. That is clearly not the case here [video image shows pigs caked in excrement]. The pig is an extremely clean animal that tries to avoid contact with its own faeces." (Animal welfare professor, A-Studio 2007)

Here, the spectator is presented with a value judgment condemning the pigs' physical surroundings as a violation of their instinctive behaviour, but only to an extent. The broader implication of the statement is that the moral code against which the on-screen events should be judged is inscribed in legislation. In the 2015 episode of A-Studio, legislation is placed in an even more prominent position through the technical means of a split screen: on the right-hand side of the screen we see activist footage, while the left-hand side displays written excerpts from the Animal Protection Act. This signals to the audiences that the animals' suffering will be alleviated once those who violate acts and decrees are appropriately punished.

Concerning aesthetic quality, the account of suffering in the television programme combines elements from two of Boltanski's (1999) topics. The dominant narrative function of description combined with the images declared authentic corresponds to sublimation, which invites the spectator to rationally contemplate the issue and draw her own conclusions about how to feel and act on it. Almost in equal measure, the media texts also refer to the topic of pamphleteering by suggesting that the situation in the piggeries is morally unjustifiable to the extent that it violates legislative norms. In line with the combination of sublimation and pamphleteering, references to the symbolic figure of the persecutor are sometimes diffused by the use of the passive voice:

"This animal is in such a bad condition that it should have been put to sleep." (Representative of pig farmers' association, A-Studio 2015)

while at other times the evildoer is explicitly verbalized as being the pig farmers, as in the following dialogue from the 2015 episode:

Studio host: "What do these videos tell us?"

Doctor of veterinary medicine: "These videos show that we have several farms where the treatment of animals could be tremendously improved."

As the spectator is not pinpointed as a persecutor, the television programme holds a better chance in provoking her anger and directing it towards the public denouncement of the farmers and, by extension, to the relevant authorities who are supposed to monitor the farms but have not noticed or acted on the farmers' violations. The above quote is also interesting as it indicates how the television programme constructs an identity for the spectators not as a collective of potential activists but as a public represented by the host, joined together by their collective act of witnessing ("what do these videos tell us"). 


\section{Multi-functionality}

In the television programmes, the counter accounts of animal suffering acquire spatio-temporally more complex characteristics than on the activist website. Spacetimes are multiple, including for instance the studio interior in the immediate present, the timeless countryside idyll depicted at the beginning of the 2007 insert, and the dark piggeries situated both in the immediate past (voiceover: "several pigs had wounds") and the present (expert commentary: "This abscess has progressed too far"). The production halls where the pigs are kept gain additional features from the expert commentary, which helps the spectator put them in context:

"The narrowness of these pens [shown on screen] is probably in accordance with the law (...) However, many producers have realized that things run more smoothly if you give them [the pigs] a bit more room". (Animal welfare professor, A-Studio 2007)

Thus, the space is not only a homogeneous background but becomes represented as something that can be internally differentiated and is linked to the extent of suffering, the implication being that the alleviation of suffering requires the space to be enlarged.

As concerns the moral distance between the spectators and the suffering animals, the technology of mediation makes itself visible through visual editing and composition, especially in scenes where the spectator watches as the host and experts watch the videos. We conceptualize the latter as an act of double mediation where the spacetime of the videos coincides with the spacetime of the studio broadcast, fading the first-hand testimonial quality of the media texts and replacing it with the spacetime of omnipresence (Chouliaraki, 2004). This impression of the spectator being present everywhere the camera takes her reduces the urgency of the situation and divides the responsibility of taking action between the spectator and the individuals in the studio that she sees as co-witnesses.

Regarding the agency of the sufferer, in the television programme the pigs are not portrayed as actors to the same extent as in the original activist videos. In the A-Studio episodes, the sounds made by the pigs have been muted and the selected clips do not show pigs facing the camera, so there is no direct eye contact between them and the spectator. Through the expert commentary, the pigs are provided with an interiority in the form of particular characteristics such as cleanliness, curiosity and the ability to experience stress. However, they are still categorized as a different species ("the pig is...") subservient to human beings ("we must take care of our animals"), so the process of kindredization is not taken to completion. The reference to taking care of "our animals" suggests that human beings as the animals' stewards are entitled to keep them but also morally obliged to treat them humanely.

In regards to other forms of agency, at no stage of the television programmes is the spectator pinpointed as being personally responsible for the pigs' conditions; it is the negligent farmers who have "problems coping with everyday life" that are verbalized as the persecutors. Neither is the spectator presented with options for practical action; the frequent references to the Animal Protection Act suggest that the moral duty to act lies with the appropriate authorities now that the investigative journalists have brought these events to light in a purportedly objective fashion.

To summarize, our application of the analytics of mediation to the television programme showing excerpts of the counter accounts highlights how, through a technically diverse representation involving interconnected verbal and visual elements as well as complex spacetimes, the 'othering' of the animals is to 
some extent reduced and they come to be presented as worthy of our moral attention. The dominant topics are sublimation and pamphleteering, making claims to facticity and justice. The spectator's emotional potential is mainly organized around the figure of the farmer-persecutors, but she is not explicitly presented with options for practical action; at the most there are implicit references to the need to alleviate the animals' immediate conditions by conducting welfare improvements and more frequent inspections by the appropriate authorities.

\section{Discussion and conclusions}

Our purpose in this paper was to advance theoretical and empirical understanding of the moral and political dimensions associated with the transformative potential of counter accounts. In this respect, we focused on the under examined relationship between counter accounts' audiences and those suffering from the organizational or institutional activity considered harmful. In particular, we sought to find out how counter accounts mediate the suffering of distant 'others' and how that mediation in turn could stimulate public action. In empirical terms, we investigated animal rights activists' counter accounts of animal production in Finland, both as 'stand-alone reports' on animal rights organization's website and as featured in two episodes of a prime-time television programme. Drawing on Chouliaraki's analytics of mediation, we examined the counter accounts as media texts, focusing on the two dimensions of multi-modality and multi-functionality. Regarding multi-modality, we analysed the technical and semiotic means by which suffering 'others' can come to be represented as a moral cause for the spectators. Regarding multi-functionality, we examined how the representations of spacetimes and agency can make a normative proposal to the spectators in terms of how to act on the suffering. We also illustrated how the suffering comes to acquire different meanings depending on the technical and semiotic choices employed in its mediation.

We believe our research to make two main contributions to extant knowledge. First, we complement the literature on the transformative potential of counter accounts (Cooper et al. 2005, Brown \& Dillard 2013, Brown et al. 2015, Gallhofer et al. 2015, Spence 2009, Tregidga et al., in press) by focusing on the thus far neglected moral dimension, in particular the mechanism of moral engagement that is associated with the emergence of collective action. Second, we illustrate the value of Chouliaraki's (2006a et seq) and Boltanski's (1999) conceptualizations to the study of multi-modal accounts, thus expanding the methodological toolbox of discourse analyses to include also visual aspects. In doing so, we also respond to recent calls for more theoretically diverse and robust analyses of accounting in the context of sustainability (Gray, 2010; Bebbington \& Larrinaga, 2014; Unerman \& Chapman, 2014). Before we elaborate on these contributions, however, we would like to take the opportunity to reflect on the relationship between counter accounts and more conventional notions of accounting.

\section{Counter accounts as a form of accounting}

A critical commentator might well ask which features of counter accounts distinguish them from mere 'alternative representations' and thus warrant their inclusion within the ambit of accounting instead of, for instance, cultural studiesio. In our view, counter accounts are an illustration of the low epistemological threshold of accounting (M iller, 1998). As noted by M iller (1998), the margins of accounting are pushed when the problematization of extant practices leads to the incorporation of elements from other social practices.

10 Reflecting on these issues is important to prevent the uncontrolled expansion of the domain to the extent where every act of communication would be considered an instance of accounting (Gallhofer et al., 2015; cf. Gray et al., 1996). We thank one of the anonymous reviewers for pointing this out and encouraging us to discuss the matter. 
In a general sense, counter accounts can be said to problematize the conventional notions of accounting, which revolve around providing investors and creditors with quantitative, predominantly financial, information about economic entities for the purposes of decision-making and assessing management's accountability (Accounting Principles Board, 1970; International Accounting Standards Board, 2010). Our study indicates that counter accounts can indeed be included in the domain of accounting since it is possible to characterize them using all three key elements of the conventional definitions - information, users, and decisions; each of these just needs to be understood in a broad sense. First, counter accounts may well comprise financial and other quantitative information about distinct economic entities, but also qualitative and non-financial information concerning entire industries or governance regimes. Second, in line with stakeholder theory (Freeman, 1984), counter accounts' understanding of the users of such information encompasses not only investors and creditors but also other interested constituencies, such as suppliers, customers, employees, governments and the public at large. Third, these groups are hoped to utilize the information provided in counter accounts for making not only economic decisions but also moral and political ones.

Particularly the second and third points above are, in our view, linked to Chouliaraki's and Boltanski's works that consider the moral and political dimensions to be intertwined and open for public contestation. Both authors seem to acknowledge the possibility of multiple publics with heterogeneous ethical views, standpoints regarding the type of collective action necessary and visions of social change sought. These issues become most apparent in Chouliaraki's (2013) recent suggestions regarding how to resurrect humanitarian communication, which she argues is plagued by compassion fatigue on the one hand and the de-politicizing tendencies of neoliberalism on the other. She argues for 'agonistic solidarity', a form of communication that comprises the elements of both empathy and judgement. While empathetic identification with the 'other' gives rise to a moral imperative to act on her suffering, the element of judgement invites contemplation of ethico-political questions concerning "why this suffering is important and what there is to do about it but also why suffering, as a symptom of injustice, is perpetuated and what can be done to change its conditions of existence" (ibid., p. 194, emphasis in the original). What such a position implies for counter accounts, then, is that they need not aspire towards the purported neutrality of conventional financial disclosures but can be open about the social values that have prompted their construction and refer explicitly to a vocabulary of justice (see Cooper et al., 2005).

\section{The transformative potential of counter accounts}

The mediation of an oppressed group's suffering can give rise to political action if, first, individual spectators consider the suffering to be worthy of their moral attention; and second, those individuals sympathize with the suffering 'others' to the extent of being willing to engage in public action (Chouliaraki, 2006a, 2008). Regarding the first requirement, our analysis suggests that counter accounts can morally engage spectators with a combination of technical, visual and verbal cues that simultaneously present the suffering as an objective fact and make an emotional appeal to the spectator. The online counter accounts give the impression of an authentic first-hand testimony through the use of an involved camera and gaze-level video image accompanied by factual first-layer texts, while the television programme relies on the authenticity provided by an omnipresent camera with prominent visual editing and expert commentary that expands on the video images. In terms of emotional identification, both the television programme and the second-layer texts of the online counter accounts seek to morally engage the spectators by representing the suffering as an injustice. However, the two types of mediation differ in terms of the nature of the injustice and the symbolic figure of the evil-doer. As animal rights activists seek justice for all forms of life, their online counter 
accounts verbalize the problem as the institutionalized practice of meat production and consumption, referring to multiple persecutors including the meat-eating spectator, national customs and the meat producers. Here, the counter accounts exhibit elements of a theoretically informed understanding of social totality and its contradictions as recommended by Cooper et al. (2005) but do not explicitly link the animal rights issue to contemporary struggles against the prevailing structural arrangements. The television programme in turn utilizes various semiotic means to confine the injustice to the animals' concrete surroundings, drawing on prevailing societal norms as reflected in legislation, and narrowing the cast of persecutors to farmers.

As concerns the second precondition for the emergence of collective action, namely the activation of the spectator's emotional potential, counter accounts need to evoke the spectator's sympathy towards the oppressed group and present her with practical options on how to act on the suffering. In discursive terms, counter accounts need to construct an identity for the sufferers as sovereign fellow individuals constrained by unjust circumstances and an identity for the spectators as a public, a collective of potential activists. In our analysis, the first-layer media texts of the online counter accounts arguably do not succeed in lessening the 'othering' of the oppressed group. The simple, categorical representation of spacetime does not expand the spectator's horizon to the contemplation of the historical and structural context of the suffering but anchors the phenomenon in the physical circumstances of the present, while the factual depiction of the pigs only in the act of suffering, without interpreting voiceover, overshadows their capabilities and deprives them of internal depth and agency. The second-layer texts of the online counter accounts are much more explicit in their attempt at kindredization as they point out similarities between pigs and human beings. These texts also construct an identity for the spectator as a potential activist, suggesting that she start by changing her personal habits and then continue to action on behalf of animals as well as monetary sponsoring. By embedding a hyperlink to the local chapters of the animal rights organization $\mathrm{OE}$ into the text, these counter accounts also evoke a sense of the individual spectator as part of a public with a joint cause.

The A-Studio episodes in contrast make use of multiple spacetimes and expert commentary to vest the pigs with a degree of agency and mental capabilities that justify their right to be treated properly by their human stewards. Yet, the process of kindredization is not taken to completion, as that would signify challenging the status quo. Even though the television programme classifies the oppressed group as worthy of the spectator's moral attention, it does not explicitly propose that she take public action. The individual spectators are addressed as a collective represented by the studio host, as indicated by his use of the collective term "we" when asking questions from the experts (e.g. "What do these videos tell us?"). Yet, the frequent references to legislation in force, as well as the momentary acts of double mediation where the spectator, studio host and experts co-witness the on-screen events, serve to diffuse the responsibility for action, ultimately placing it with the relevant authorities. The identity of the spectators is not constructed as that of potential activists joined by a moral cause but as that of a public joined by their collective act of witnessing.

In terms of Boltanski's (1999) three topics for the public staging of suffering, the combination of objectivity and reflexive judgment prevalent in both forms of counter accounts analysed in this paper are characteristic of pamphleteering, which can stimulate public action or lead to compassion fatigue depending on which emotions are activated. The outright moralization of the spectator in the online counter accounts operates through the logic of complicity, demanding that the spectator acknowledge her own responsibility in upholding the institutionalized practices portrayed as unjust, and change her consumption habits accordingly. This might provoke a contrary reaction against 'guilt-tripping' whereby the spectator rejects the moral plea and directs her anger at the other culprits, namely the farmers. Therefore, it might be that despite 
their diverging moral philosophical foundations, both forms of counter accounts end up constructing the suffering as an issue of animal welfare instead of animal rights. This outcome is somewhat ironic considering that television as a medium most likely made more people aware of the issue than would have been possible through the animal rights organization's website only. In more general terms, this finding suggests that multimodal accounts relying strongly on visual elements and perceptive realism may easily morph into a different kind of account than originally conceived. This is not to claim that the animal activists' counter accounts became subject to institutional capture but to point out that unedited footage without voiceover can easily be combined with other semiotic elements to arrive at an account that diverges from that intended.

In general terms, the transformative potential of counter accounts is related to their ability to act as a form of moral education, not unlike ancient Greek theatre, by repeatedly suggesting to the audiences how to feel about, and act publicly on, the suffering of an oppressed group. A key aspect in this process of education is counter accounts' ability to foster the audiences' imagination in terms of helping them empathize with a distant 'other'. Imagination is crucial not only for the moral engagement of an individual spectator but also for engendering collective action, as it facilitates the development of innovative visions and social imaginaries (Brown \& Dillard, 2013; Brown et al., 2015; Tregidga et al., in press). In the conceptualization of Chouliaraki and Orgad (2011), mediation as moral education would in an ideal case lead to the emergence of a cosmopolis, a space where we care about others particularly because they are different from us. This resonates with calls made in the pluralist accounting literature to respect ineradicable differences between viewpoints, and to perceive the tensions arising from such differences as fertile breeding ground for new understandings (e.g. Brown \& Dillard, 2013; Gallhofer et al., 2015; Vinnari \& Dillard, 2016). Counter accounts could play a marked role in recurrently exposing individuals to alternative viewpoints and the needs of marginalized or oppressed groups.

As concerns future imaginaries, the activists' online counter accounts do not make much use of presentational, semiotic or spatio-temporal complexity, and fail to articulate a clear alternative vision of the future. In this sense, our results diverge from those of Apostol (2015) and Spence (2009), who discuss how counter accounts produced by civil society can at times be effective in debunking a hegemonic discourse or institutionalized practices. Following Spence (2009), counter accounts should actively engage in constructing an alternative discourse for the prevailing hegemony. In the empirical context discussed in this paper, the counter accounts' ambiguity regarding the concrete terms of their alternative vision of the future leaves room for the discourse of animal welfare which acknowledges the suffering but points towards solutions that do not threaten the status quo, leaving many taken-for-granted social practices beyond discussion. The television programme featuring parts of the counter accounts exemplifies the successful use of various modes of presentation as well as verbal and visual cues that clearly articulate the moral value it promotes, the avoidance of suffering, and, by playing on nostalgic ideas of our rural past, portrays the return to smallscale, humane farming as the vision to be pursued.

\section{Analytics of mediation and the study of multi-modal accounts}

Chouliaraki's (2006a, 2008) analytics of mediation is useful for the study of multi-modal accounts for several reasons. First, by focusing on the moral relationship between the audiences and the suffering 'other', the framework allows us to study the role of counter accounts in the extra-institutional space (Brown et al., 2015), thus moving away from the corporation-centric view that has largely dominated not only prior studies on counter accounts and counter-hegemonic discourses but also the broader critical accounting literature on corporate (un)sustainability. While there is a relatively vast body of knowledge on corporate responsibility 
reports and associated discourses, we still know little of the means by which such communications are countered by critically oriented groups, such as social movement activists (Tregidga, M ilne $\&$ Lehman, 2012). Although the study at hand employed the analytics of mediation to investigate counter accounts of animal production, future studies could apply the framework in Chouliaraki's (2004; 2006a) original sense to examine how counter accounts construct the suffering of human 'others' for instance in the context of human rights or labour rights issues (see e.g. McPhail \& Ferguson, 2016). Further, shifting the focus of examination from institutions to audiences and especially those suffering would also allow for a more profound and nuanced engagement with global sustainability issues as scholars could then distinguish between various animals, plants and life-supporting processes instead of merely grouping these distinct entities under the generic label "nature". Such a reductionist view of a single nature overlooks the multiplicity of socially constructed and contested natures (Macnaghten \& Urry, 1998; Haila \& Dyke, 2006) that call for a more specific approach to making organizational impacts visible.

Second, the framework is helpful as it pays explicit attention to the mechanism through which counter accounts could be expected to attain their target, which is motivating audiences to take action leading to societal change. As mentioned above, prior literature on counter accounts and counter hegemonic discourses has already noted the significance of emotion and imagination in inducing social change (e.g. Brown et al., 2015; Spence, 2009; Tregidga et al., in press). However, the way in which emotion and imagination are associated with audiences' moral engagement and transformation into public-political actors has not been subject to detailed investigation. Thus, the analytics of mediation could be fruitfully applied to examine how counter accounts attempt to engage their audiences through the portrayal of suffering 'others' in various contexts. The above problematization can also be extended to organizational communications in a broader sense. For instance, although it has been established that various private and public sector organizations produce social and environmental reports mainly for the purpose of constructing organizational legitimacy (e.g. Aerts \& Cormier, 2009; Cho \& Patten, 2007; Vinnari \& Laine, 2013), scholars have paid scant attention to the discursive means through which such effects could be produced, intentionally or otherwise (Vaara and Tienari, 2008; Tregidga et al., 2012). In this sense, Chouliaraki's (2006a, 2008) framework could be employed to investigate how organizational communications negotiate the relationship between stakeholder audiences and those affected by the organizations' activities, possibly representing the latter as not needing the former's sympathy.

Future research could also apply the framework in combination with an examination of authentic audience reactions to establish whether the mechanisms operate in the way envisaged. In this paper we have focused only on the construction of meaning, yet we acknowledge that the transformative potential of counter accounts also relies heavily on how they are received by various audiences. Arguably, each spectator interprets a counter account through her own framework consisting of, among other things, previous life experiences and knowledge. Gauging the effectiveness of counter accounts could therefore involve a largescale investigation of socio-demographic and psychological factors associated with specific audience reactions. In more general terms, shifting the focus of scholarly interest towards audience consumption 11 of accounting disclosures and organizational communications more broadly would enable further theorization of the dynamics between the construction, mediation and reception of particular messages (Tregidga et al., 2012; see also Chouliaraki, 2015).

11 In the domain cultural studies, such research can often be located under the rubric of 'audience witnessing' or, more mundanely, 'audience reactions' (see e.g. Höijer, 2004; Kyriakidou, 2015; Seu, 2010). 
Third, in a methodological sense, Chouliaraki's framework allows us to study visual aspects, especially moving image, as representational elements that participate in the construction of discourses. Prior accounting research has focused mainly on photos and other static visualizations, conceptualizing them as works of art (Davison, 2010), rhetorical devices (Davison, 2014) or actors with performative effects (e.g. Justesen $\&$ M ouritsen, 2008; Quattrone, 2009; Pollock \& D'Adderio, 2012). To our knowledge, the present paper is the first in the accounting literature to examine moving image from a discourse theoretical perspective. Conversely, the analytics of mediation expands critical discourse analysis to the study of multi-modal accounts, bringing an added dimension to the study of intertextuality as cross-references between the verbal and the visual elements. The framework is also useful as it allows the examination of how the same semiotic element can acquire different meanings depending on the way in which it is visually and verbally framed. This opens up the possibility to contrast how the accounts of for instance social movements and corporations frame the same semiotic element, be it a phrase, photo, or video clip. In a more general sense, the analytics of mediation with its tentative list of analytical questions responds to Meyer et al.'s (2013) call for a systematic approach to the study of visual aspects in the fields of both accounting and organization studies. Such analyses need not be limited to counter accounts but could just as well be applied to the critical study of corporate websites, which contain an increasing amount of moving image such as video clips featuring CEOs, other executives, employees and stakeholders.

\section{Practical implications}

As concerns the practical implications of our study, our analysis of Finnish animal activists' counter accounts allows us to offer the following recommendations. First, not unlike their equivalents in the corporate world, counter accounts would benefit from a clearly expressed vision. In the animal industry case, the counter accounts on the activist website do not offer the spectator a clear indication of what a future without animal production could be like; they only approach the issue through negation (status quo is unacceptable), whereas the television programme connects animal suffering to an explicit solution, a return to past, "humane" practices. As moral engagement in this case implies not only political action but also that the spectator would fundamentally change her dietary habits, she would most likely want to be advised in practical matters such as how to replace animal-derived products. In this light, attempts to avoid being too explicit about the need to abolish animal production run the risk of leaving the action space open for competing, less radical solutions such as welfarist reforms.

Second, and on a related note, instead of relying only on the power of the image to convince audiences of the need for radical change, the producers of counter accounts would do well to complement images of suffering with other visual and verbal elements that would increase the spectator's understanding of animal capabilities and explicitly articulate the moral case for abolishing animal production. This might include the use of various forms of counter accounts over multiple episodes of resistance, as proved useful in the case of resistance against existing modes of tobacco governance discussed by Thomson and colleagues (2015). It is likely that counter accounts not only need to engage in persistent critique of the entity or practice considered harmful over an extended period of time, but also are required to evolve in mode and content as the institution under critique reacts and develops over time (see Brennan and M erkl-Davies, 2014).

\section{Limitations and further research needs}

The first limitation of this study comprises a set of practical difficulties associated with the application of the analytics of mediation (Chouliaraki, 2006 et seq). The distinction between the two dimensions of multimodality and multi-functionality is conceptually justified yet difficult to narrate without resorting to 
repetition. Moreover, the framework consists of numerous analytical questions and its comprehensive application is only feasible in the case of relatively short news broadcasts. As the length of the programme episodes we analysed considerably exceeds that of television news, we necessarily had to employ the framework as a heuristic and focus on the aspects we considered most relevant from the perspective of our research question.

The second limitation is typical of discourse analyses more generally, in that the analysis presented in this paper is limited to our own perspective as spectators. This observation supports our above call for further studies of audience responses to witnessing multi-modal (counter) accounts and other organizational communications. A final limitation is the relatively static nature of our study, which focuses on the content and media of the counter accounts. We therefore identify the need for more dynamic studies on the actualization (or not) of counter accounts' intended effects.

\section{References}

Aaltola, E. (2012). Animal Suffering: Philosophy and Culture. London: Palgrave M cM illan.

Accounting Principles Board (1970). Statement No. 4, Basic Concepts and Accounting Principles Underlying Financial Statements or Business Enterprises. New York: American Institute of Certified Public Accountants, paragraph 40.

Aerts, W. \& Cormier, D. (2009). M edia legitimacy and corporate environmental communication. Accounting, Organizations and Society, 34(1), 1-27.

Alvesson, M . \& Kärreman, D. (2011). Decolonializing discourse: Critical reflections on organizational discourse analysis. Human Relations, 64(9), 1121-1146.

Annas, J. (2006). Virtue Ethics. In: David Copp (ed.). The Oxford Handbook of Ethical Theory. Oxford: Oxford University Press, pp. 515-36.

Apostol, O.M . (2015). A project for Romania? The role of the civil society's counter accounts in facilitating democratic change in society. Accounting, Auditing \& Accountability Journal, 28(2), 210 - 241

Archel, P., Husillos, J., \& Spence, C. (2011). The institutionalisation of unaccountability: Loading the dice of Corporate Social Responsibility discourse. Accounting, Organizations and Society 36, 327-343.

Arendt, H. (1973/ 1990). On Revolution. London: Penguin.

Arnold, P. and Hammond, T. (1994). The role of accounting in ideological conflict: lessons from the South African divestment movement. Accounting, Organisations and Society, 19(2), 111-126.

Bebbington, J. \& Larrinaga, C. (2014). Accounting and sustainable development: An exploration. Accounting, Organizations and Society, 39(6), 395-413.

Bebbington, J. \& Thomson, I. (2013). Editorial: Sustainable development, management and accounting: Boundary Crossing. M anagement Accounting Research, 24, 277-283.

Bebbington, J., Unerman, J. \& O'Dwyer, B. (2014). Sustainability Accounting and Accountability. Abingdon: Routledge. 
Bentham, J. (1789/1961). An Introduction to the Principles of M orals and Legislation. Garden City:

Doubleday.

Birkin, F., Edwards, P. and Woodward, D., (2005). Accounting's Contribution to a Conscious Cultural Evolution. Critical Perspectives on Accounting, 16(3), 185-208.

Boiral, O. (2013). Sustainability reports as simulacra? A counter account of A and A+GRI reports. Accounting, Auditing and Accountability Journal, 26(7), 1036-1071.

Boltanski, L. (1999). Distant Suffering: Media, Morality and Politics.

Brennan, N.M . \& M erkl-Davies, D.M . (2014). Rhetoric and argument in social and environmental reporting: the Dirty Laundry case. Accounting, Auditing \& Accountability Journal, 27(4), 602 - 633.

Brink, D. (2006). Some forms and limits of consequentialism. In: D. Copp (ed.). The Oxford Handbook of Ethical Theory. Oxford: Clarendon Press.

Brown, J. 2010. Accounting and visual cultural studies: potentialities, challenges and prospects. Accounting, Auditing \& Accountability Journal, 23(4), 482 - 505.

Brown, J. \& Dillard, J. (2013). Agonizing over engagement: SEA and the "death of environmentalism" debates. Critical Perspectives on Accounting, 24(1), 1-18.

Brown, J., Dillard, J. \& Hopper, T. (2015). Accounting, accountants and accountability regimes in pluralistic societies. Accounting, Auditing \& Accountability Journal, 28(5), 626 -650.

Cho C.H., Laine M., Roberts R.W. and Rodrigue M. (2015). Organized Hypocrisy, Organizational Façades, and Sustainability Reporting. Accounting, Organizations and Society, 40(1), 78-94.

Cho, C. H., \& Patten, D. M. (2007). The role of environmental disclosures as tools of legitimacy: A research note. Accounting, Organizations and Society, 32(7-8), 639-647.

Chouliaraki, L. (2004). Watching September 11: The politics of pity. Discourse Society, 15(2-3), 185-198.

Chouliaraki, L. (2006a). Towards an analytics of mediation. Critical Discourse Studies, 3(2), 153-178.

Chouliaraki, L. (2006b). The aestheticization of suffering on television. Visual Communication, 5(3), 261285.

Chouliaraki, L. (2008). The Spectatorship of Suffering. London: SAGE Publications.

Chouliaraki, L. (2010). Post-humanitarianism: Humanitarian communication beyond a politics of pity. International J ournal of Cultural Studies, 13(2), 107-126.

Chouliaraki, L. (2013). The Ironic Spectator: Solidarity in the Age of Post-Humanitarianism. Cambridge: Polity Press.

Chouliaraki, L. (2015). Afterword: The dialectics of mediation in 'distant suffering studies'. The International Communication Gazette, 77(7), 708-714. 
Chouliaraki, L. \& Orgad, S. (2011). Proper distance: M ediation, ethics, otherness. International J ournal of Cultural Studies, 14(4), p. 341-345.

Cooper, C., Taylor, P., Smith, N., \& Catchpowle, L. (2005). A discussion of the political potential of social accounting. Critical Perspectives on Accounting, 16, 951-974.

Davison, J. (2010). [In]visible [in]tangibles: Visual portraits of the business élite. Accounting, Organizations and Society 35, 165-183.

Davison, J. (2014). Visual rhetoric and the case of intellectual capital. Accounting, Organizations and Society, 39, 20-37.

Dey C., Russell, S., \& Thomson, I. (2011). Exploring the potential of shadow accounts in problematising institutional conduct. In Osbourne, S., \& Ball, A. (Eds.) Social accounting and public management: Accountability for the common good. Routledge, Abingdon, 64-75.

Dillard, J. \& Vinnari, E. (in press). A case study of critique: Critical perspectives on critical accounting. Critical Perspectives on Accounting. dx. doi.org/10.1016/j.cpa.2016.09.004

Dryzek, J.S. (1997). The Politics of the Earth: Environmental Discourses. Oxford UP, New York.

Fairclough, N. (2010). Critical discourse analysis: The critical study of language. Harlow: Longman/Pearson.

Flyvbjerg, B. (2001). Making social science matter. Cambridge: Cambridge University Press.

Foucault, M. (1981). The History of Sexuality: An Introduction. Harmondsworth, Mx: Penguin.

Francione, G. (1996). Rain without thunder: The ideology of the animal rights movement. Temple University Press.

Francione, G. \& Charlton, A. (2013). Eat Like You Care: An Examination of the M orality of Eating Animals. Exempla Press.

Freeman, R.E. (1984). Strategic Management: A Stakeholder Approach. Boston: Pitman.

Gaffikin, M. (2009). Twenty-one years of critical resistance - Almost: A reflection. Accounting Forum, 33, 268-273.

Gallhofer, S., Haslam, J., M onk, E., \& Roberts, C. (2006). The emancipatory potential of online reporting: The case of counter accounting. Accounting, Auditing and Accountability Journal, 19(5), 681-718.

Gallhofer, S., Haslam, J. \& Yonekura, A. (2015). Accounting as differentiated universal for emancipatory praxis. Accounting, Auditing \& Accountability Journal, 28(5), $846-874$.

Golsorkhi, D., Leca, B., Lounsbury, M. and Ramirez, C. (2009), Analysing, accounting for and unmasking domination: On our role as scholars of practice, practitioners of social science and public intellectuals. Organization, 16(6), 779-797.

Gray, R. (2010). Is accounting for sustainability actually accounting for sustainability. . . and how would we know? An exploration of narratives of organisations and the planet. Accounting, Organizations and Society $35,47-62$. 
Gray R., Adams, C.A. and Owen, D. (2014). Accountability, Social Responsibility and Sustainability. Accounting for Society and the Environment. Harlow, UK: Pearson.

Gray, R., Brennan, A. \& Malpas, J. (2014). New accounts: Towards a reframing of social accounting. Accounting Forum, 38(4), 258-273.

Gray, R., Owen, D. and Adams, C. (1996). Accounting and Accountability: Changes and Challenges in Corporate Social and Environmental Reporting. Hemel Hempsted: Prentice Hall.

Haila, Y., \& Dyke, C. (Eds.). (2006). How nature speaks? The dynamics of the human ecological condition. Durham: Duke University Press.

Hardy, C. \& Phillips, N. (1999). No joking matter: Discursive struggle in the Canadian refugee system. Organization Studies, 20(1), 1-24.

Harte, G. \& Owen, D. (1987). Fighting de-industrialisation: The role of local government social audits. Accounting, Organizations and Society, 12(2), 123-141.

Hopwood, A. G. (2009). Accounting and the environment. Accounting, Organizations and Society, 34(3-4), 433-439.

Höijer, B .(2004). The discourse of global compassion: the audience and the media reporting of human suffering. M edia, Culture \& Society, 26(4), 513-531.

International Accounting Standards Board (2010). The Conceptual Framework for Financial Reporting. London: IFRS Publications Department.

Justesen, L. \& M ouritsen, J. (2008). The triple visual: Translations between photographs, 3-D visualizations and calculations. Accounting, Auditing \& Accountability Journal, 22(6), 973-990.

Jørgensen, M. \& Phillips, L. (2002). Discourse Analysis as Theory and M ethod. London, SAGE Publications.

Konttinen, E. \& Peltokoski, J. (2004). Ympäristöprotestin neljäs aalto. Eläinoikeusliike ja uuden polven ympäristöradikalismi 1990-luvulla. [The Fourth Wave of Environmental Protest. The Animal Rights M ovement and the New Generation of Environmental Radicalism in the 1990s]. Jyväskylä, M inerva Publications Ltd.

Kyriakidou, M . (2015). M edia witnessing: exploring the audience of distant suffering. M edia, Culture \& Society, 37(2), 215-231.

Laclau, E. and Mouffe, C. (2001/1985), Hegemony and Socialist Strategy: Towards a Radical Democratic Politics, Second edition. Verso, London.

Lang, T., Barling, D., \& Caraher, M. (2009). Food policy. Integrating health environment and society. Oxford: Oxford University Press.

Lehman, G. (1999). Disclosing new worlds: a role for social and environmental accounting and auditing. Accounting, Organizations and Society, 24(3), 217-241.

M acnaghten, P., \& Urry, J. (1998). Contested Natures. London: Sage. 
M cM ichael, J., Powles, C. and Butler, R. (2007). Food, livestock production, energy, climate change, and health. Lancet, 370, 1253-1263.

M cPhail, K. \& Ferguson, J. (2016). The past, the present and the future of accounting for human rights. Accounting, Auditing \& Accountability Journal, 29(4), 526 - 541.

M essner, M . (2009). The limits of accountability. Accounting, Organizations and Society, 34, 918-938.

M eyer, R.E., Höllerer, M.A., Jancsary, D. and van Leeuwen, T. (2013). The visual dimension in organizing, organization, and organization research: Core ideas, current developments, and promising avenues. The Academy of Management Annals, Vol. 7, No. 1, 489-555.

M ill, J. S. (1861/1998). Utilitarianism (edited with an introduction by Roger Crisp). New York: Oxford University Press.

M iller, P. (1998). The margins of accounting. The European Accounting Review, 7(4), 605-621.

Phillips, N. and Hardy, C. (2002), Discourse Analysis: Investigating Processes of Social Construction, Sage University Papers Series on Qualitative Research M ethods, Vol. 50. Sage, Thousand Oaks, CA.

Phillips, N. \& Oswick, C. (2012) Organizational Discourse: Domains, Debates, and Directions. The Academy of Management Annals, 6(1), 435-481.

Pollock, N. \& D’Adderio, L. (2012). Give me a two-by-two matrix and I will create the market: Rankings, graphic visualisations and sociomateriality. Accounting, Organizations and Society 37, 565-586.

Quattrone, P. (2009). Books to be practiced: Memory, the power of the visual, and the success of accounting. Accounting, Organizations and Society 34, 85-118.

Regan, T. (1983). The Case for Animal Rights. University of Carolina Press.

Rockström, J., Steffen, W., Noone, K., Persson, A., Chapin, F. S., Lambin, E. F., Foley, J. A., 2009. A safe operating space for humanity. Nature 461(7263), 472- 475.

Seu, I.B. (2010). Doing denial: audiences' reactions to human rights appeals. Discourse and Society, 21(4), 438-457.

Sikka, P. (2006). The internet and possibilities for counter accountings: some reflections. Accounting, Auditing and Accountability Journal, 19(5), 759-769.

Sinnott-Armstrong, W. (2015). Consequentialism. The Stanford Encyclopedia of Philosophy (Winter 2015 Edition). Edward N. Zalta (ed.), URL = «ttps://plato.stanford.edu/archives/win2015/entries/consequentialism/>.

Smith, A. (1759/2010). Theory of M oral Sentiments. London: Penguin.

Spence, C. (2009). Social accounting's emancipatory potential: A Gramscian critique. Critical Perspectives on Accounting, 20(2), 205-227.

Steffen, W., Richardson, K., Rockström, J., Cornell, S.E., Fetzer, I., Bennett, E.M., Biggs, R., Carpenter, S.R., de Vries, W., de Wit, C.A., Folke, C., Gerten, D., Heinke, J., Mace, G.M., Persson, L.M., Ramanathan, V., Reyers, 
B. \& Sörlin, S. (2015). Planetary Boundaries: Guiding human development on a changing planet. Science, 13 February 2015, 347(6223).

Stehfest, E., van Bouwman, L., Vuuren, D. P., den Elzen, M. G. J., Eickhout, B., \& Kabat, P. (2009). Climate benefits of changing diet. Climatic Change, 95, 83-102.

Thomson, I., Russell, S., Dey, C. (2015). Activism, arenas and accounts in conflicts over tobacco control. Accounting, Auditing \& Accountability Journal, 28(5), 809-845.

Tregidga, H., M ilne, M . \& Kearins, K. (in press). Ramping up resistance: Corporate sustainable development and academic research. Business \& Society. doi:10.1177/0007650315611459.

Tregidga, H., Milne, M. \& Kearins, K. (2014). (Re)presenting 'sustainable organizations'. Accounting, Organizations and Society, 39(6), 477-494.

Tregidga, H., M ilne, M . \& Lehman, G. (2012). Analyzing the quality, meaning and accountability of organizational reporting and communication: Directions for future research. Accounting Forum, 36, 223230.

Unerman, J. \& Chapman, C. (2014). Academic contributions to enhancing accounting for sustainable development. Accounting, Organizations and Society, 39(6), 385-394.

Vaara, E. \& Tienari, J. (2008). A discursive perspective on legitimation strategies in multinational corporations. Academy of Management Review, 33(4), 985-993.

Vinnari, E. \& Laine, M. (2013). Just a passing fad? The diffusion and decline of environmental reporting in the water sector. Accounting, Auditing \& Accountability Journal, 26(7), 1107 - 1134.

Vinnari, E. \& Vinnari, M . (2005). Kansalaisjärjestöjen rooli maailman muuttamisessa - Animalia ja M aan ystävät (In English: The role of NGOs in changing the world - Animalia and Friends of the Earth). Futura 4, 89-97.

Vinnari, E. \& Dillard, J. (2016). (ANT)agonistics: Pluralistic politicization of, and by, accounting and its technologies. Critical Perspectives on Accounting, 39, 25-44.

Vitousek, P., M ooney, H., Lubchenco, J., \& M elillo, J. (1997). Human domination of Earth's ecosystems. Science, 277, 494-499. 


\section{APPENDIX 1 A compilation of Chouliaraki's (2006a, 2008) analytics of mediation}

\section{Dimension I: Multi-modality}

1) Mode of representation

- Is the news introduced in the studio? Is it supported by visual material? Is it reported on location?

- What sense of news realism is being evoked in the news?

- If the suffering is shown at all, is it shown in a manner that seeks to evoke a 'this-is-how-it-is' type of reality? Or does the emphasis fall more on a 'this-is how-we-feel-about-it' or 'this-is-howsad-horrific - wrong' the suffering is? Does the emphasis of the narrative make an appeal to the spectator's sense of compassion, sense of righteousness or sense of justice? Alternatively, does it refrain from engaging the spectator in a sustained emotional relationship with the piece of news?

2) Visual-verbal correspondence

- Visual

- What kind of visual representation does the suffering take in the news report? Is it graphic (map, diagram), photographic, archive film or live transmission?

- If graphic, is the representation static and minimal or dynamic and multiple (computerized, as for example, in Iraq war maps)?

- If there is written text, how does it interact with the image? Does the text add to the image (explicate, illustrate) or is it decorative, running simply in parallel to it?

- If video:

- $\quad$ What point of view (above and afar or involved)?

What angle (direct/gaze level or oblique/profile or back filming)?

What framing (actors' position; distance from camera; relationship to the overall visual composition)?

What vectors of movement (between actors; towards the spectator; outside camera frame)?

- Verbal

- Is the news verbal text cast as a description of facts? Or does the text also entail elements of exposition, with value judgements and normative proposals about the suffering? Could the news report be a narration of events with emphasis on drama and suspense and with little consideration of the facts?

- If the report combines more than one narrative type, how do these relate to one another? Which one frames the rest? What role do the subserving narratives play in the development of the story?

- Verbal and visual

- $\quad$ What role does each mode, language and image, play in the news narrative? Do the verbal and the visual mode unfold in parallel worlds with a minimal relationship between them? Or is there a substantial referential relationship between the two?

- $\quad$ If there is direct reference between visual and verbal, does the verbal 'accompany' the visual in a strictly factual narrative of depicted events or does the verbal expand on the visuals?

- If the verbal expands upon the visual, what is the 'transfer effect' of language over the visual? What extra-pictorial meanings does the news narrative evoke, by means of an 'overinterpreting' voiceover? Alternatively, does the voiceover stop to allow for the power of the visual or of sound effects to come through? 
- How does this type of verbal-visual combination impact upon the processes of news meaning making?

3) Aesthetic quality

No questions

\section{Dimension II: Multi-functionality}

1) Spacetime

- Space

- Is space actively shaping action or is it only a background to action?

- Is space replaceable or unique?

- $\quad$ Is space internally differentiated or is it presented as a homogeneous entity?

- $\quad$ Are the spaces of danger and safety in any form of interaction with one another or are they strictly separated?

- $\quad$ Time

- Is the event taking place in the present or in the past?

- $\quad$ Is time open, with multiple possibilities or is it scripted in advance?

- $\quad$ How does the past impinge on the present?

- How does it impinge on possible futures?

- What has the greatest value: the past, present or future?

- Which future - distant or immediate?

2) Agency

- Sufferer's voice and humaneness

- $\quad$ Is the sufferer given a voice, in language or in image?

- What kind of interiority is available to the sufferer? Is there a public-private boundary that gives her a certain 'depth' of consciousness?

- $\quad$ Does the sufferer co-exist or communicate with another or with other agents of suffering? What kind of ethical responsibility obliges these other agents in action?

- How does the sufferer connect with or communicate with the spectator? What kind of responsibility obliges the spectator in what type of action?

- $\quad$ Presence of agents in suffering

- $\quad$ Is the scene of suffering populated by agents?

- If yes, who participates in the suffering and in what capacity?

- Does the text evoke or explicitly represent a benefactor - individual or collective - acting to alleviate suffering? Does it evoke a persecutor - individual or collective - inflicting the suffering?

- What is the overall dramaturgical composition of these figures? What potential for emotion and/or practical action does this composition induce? 
Appendix 2 Empirical material

\begin{tabular}{|l|l|l|l|}
\hline Date & Activist videos & $\begin{array}{l}\text { Associated website (translated } \\
\text { into English) }\end{array}$ & $\begin{array}{l}\text { Associated } \\
\text { programme }\end{array}$ \\
\hline November 2007 & $\begin{array}{l}60 \text { piggeries } \\
21 \text { broiler farms } \\
20 \text { henneries }\end{array}$ & www.tehotuotanto.net & A-Studio 28.11.2007 \\
\hline December 2009 & 30 piggeries & $\underline{\text { www.sikatehtaat.fi }}$ & A-Studio 13.4.2010 \\
\hline November 2011 & 15 piggeries & as above & A-Studio 21.11.2011 \\
\hline $\begin{array}{l}\text { November 2013 } \\
\text { onwards }\end{array}$ & $\begin{array}{l}23 \text { piggeries } \\
11 \text { cattle farms } \\
\text { 2 henneries } \\
2 \text { broiler farms } \\
\text { 4 slaughterhouses }\end{array}$ & $\underline{\text { www.elaintehtaat.fi }}$ & \\
\hline
\end{tabular}

